\title{
A Solitary Volar Extradigital Glomus Tumor Mimicking a Painful Ganglion
}

\author{
Dae-Geun Kim ${ }^{a}$ Seung-Rim Kang ${ }^{b}$ \\ aDepartment of Orthopedic Surgery, Soonchunhyang University Gumi Hospital, Soonchunhyang \\ University College of Medicine, Gumi, Republic of Korea; ${ }^{b}$ Department of Radiology, Soonchunhyang \\ University Gumi Hospital, Soonchunhyang University College of Medicine, Gumi, Republic of Korea
}

\author{
Keywords \\ Glomus tumor · Extradigit · Ganglion
}

\section{Abstract}

Glomus tumors are neoplasms arising from the glomus body, which regulate skin temperature. They are mostly benign tumors and present in the subungual area of a distal phalanx. However, they can occur in extradigital location, and they may not be typical of intradigital glomus tumors. This makes it difficult to diagnose extradigital glomus tumors. We report a volar extradigital tumor mimicking a painful ganglion with a literature review.

(C) 2021 The Author(s).

Published by S. Karger AG, Basel

\section{Introduction}

Glomus tumors are approximately 1-5\% of all hand tumors [1]. They are kind of vascular neoplasms from glomus body which controls blood pressure and temperature by regulating blood flow in the cutaneous vasculature [2]. They have typical symptoms such as stabbing paroxysmal pain in the fingertips, tenderness, and cold intolerance [3]. Although these tumors could be found anywhere throughout the body, most of them occur in a distal phalanx of the fingers, often subungual area. If these tumors occur in extradigital site, it might be misdiagnosed such as ganglion, epidermal cyst, and neuroma. We present a case of extradigital glomus tumor mimicking a painful ganglion with a literature review.

\section{Case Report}

A 52-year-old female came to the outpatient clinic with a tiny palpable mass on her left hand. The mass, which had been growing for 10 months, induced a sharp stab of pain when touched. On physical examination, the mass was tiny, soft, and well-margined. The clinic which she visited first diagnosed a painful ganglion and recommended the surgery.

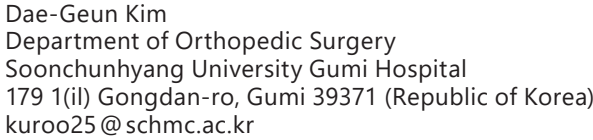


Fig. 1. MRI revealed that a well-defined rounded mass in the volar side of the third web space. a The mass showed low-signal intensity on T1weighted images. b It was high-signal intensity on T2-weighted images. c Also, it was enhanced very homogeneously.
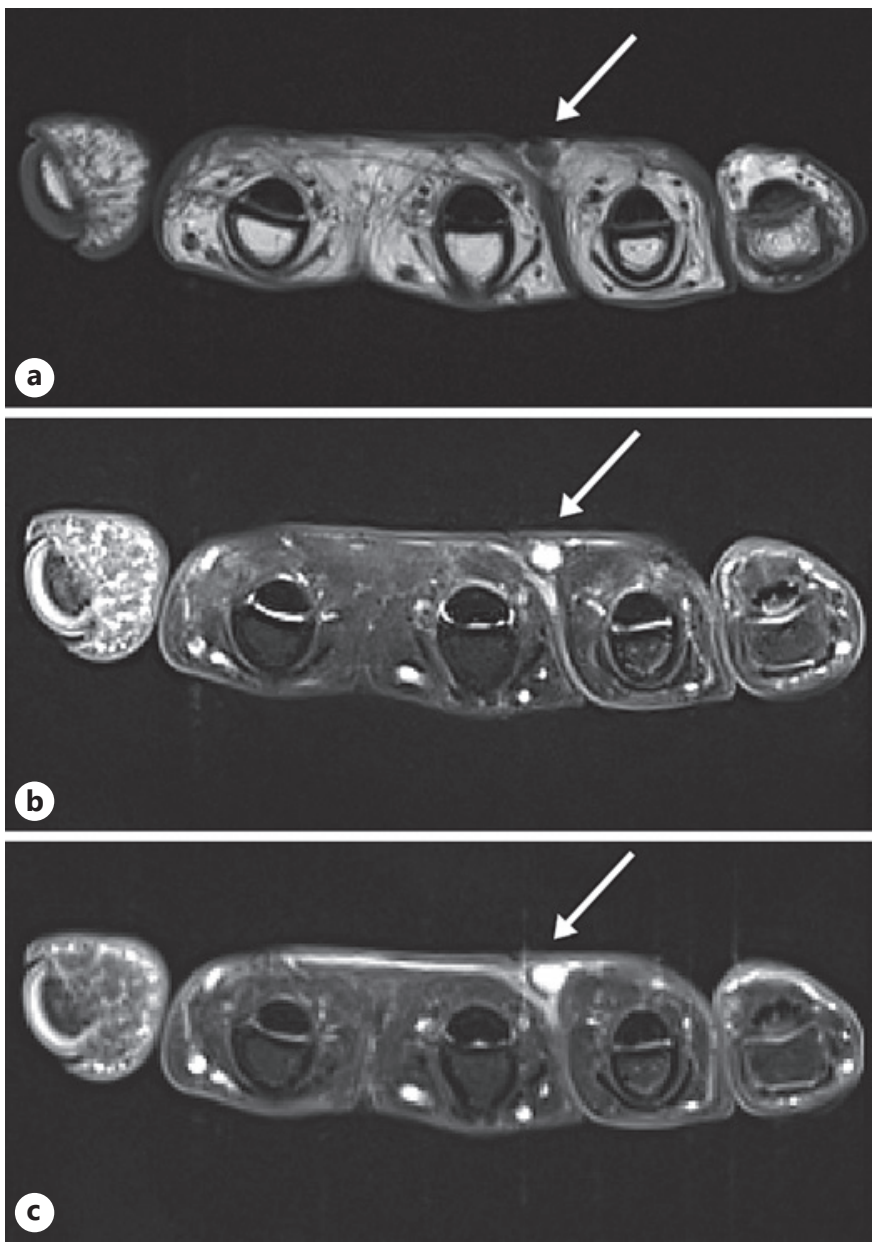

We performed a MRI with contrast. The MRI showed a well-defined rounded mass measuring $0.4 \times 0.4 \times 0.4 \mathrm{~cm}^{3}$ in the volar side of the third web space. The signal of mass was low-signal intensity on T1-weighted images and high-signal intensity on T2-weighted images. The mass revealed strongly homogeneous strong enhancement (Fig. 1). Therefore, the preoperative diagnosis would be an extradigital glomus tumor.

The patient underwent open excision of the mass under the brachial plexus block. The mass was located in the subcutaneous layer. The gross feature of the tumor was a yellowish, solitary, and well-capsulated tiny mass. The histological findings revealed the equally spaced cells, polygonal cells with identifiable cellular borders, moderate clear cytoplasm, and thinwalled blood vessels (Fig. 2). For the confirmation of glomus tumor, smooth muscle actin (SMA) and CD34 were stained in the tumor cells (Fig. 3). Symptoms improved immediately after surgery, and then there was no recurrence after the 1 year of follow-up.

\section{Discussion}

A glomus body is a neuromyoarterial apparatus located in the reticular dermis, which controls body temperature by regulating blood flow to the skin. A glomus tumor is a neoplasm of the normal glomus body. It was first described clinically by Wood [4] in 1812 and confirmed pathologically and named "glomus tumor" by Masson [5] in 1924. 
Case Reports in Orthopedic Research

Fig. 2. Microscopic images revealed that equally spaced cells (cookie-cutter appearance), polygonal cells with identifiable cellular borders, moderate clear cytoplasm, and thin-walled blood vessels $(\mathrm{H}$ and $\mathrm{E}, \times 200)$.

Fig. 3. Immunohistochemistry revealed diffuse, high SMA expression. SMA, smooth muscle actin.

\begin{tabular}{l|l}
\hline Case Rep Orthop Res 2021;4:6-10 \\
\hline DOI: 10.1159/000511427 & $\begin{array}{l}\text { C 2021 The Author(s). Published by S. Karger AG, Basel } \\
\text { www.karger.com/cio }\end{array}$ \\
\hline
\end{tabular}

Kim and Kang: Extradigital Glomus Tumor Mimicking Ganglion
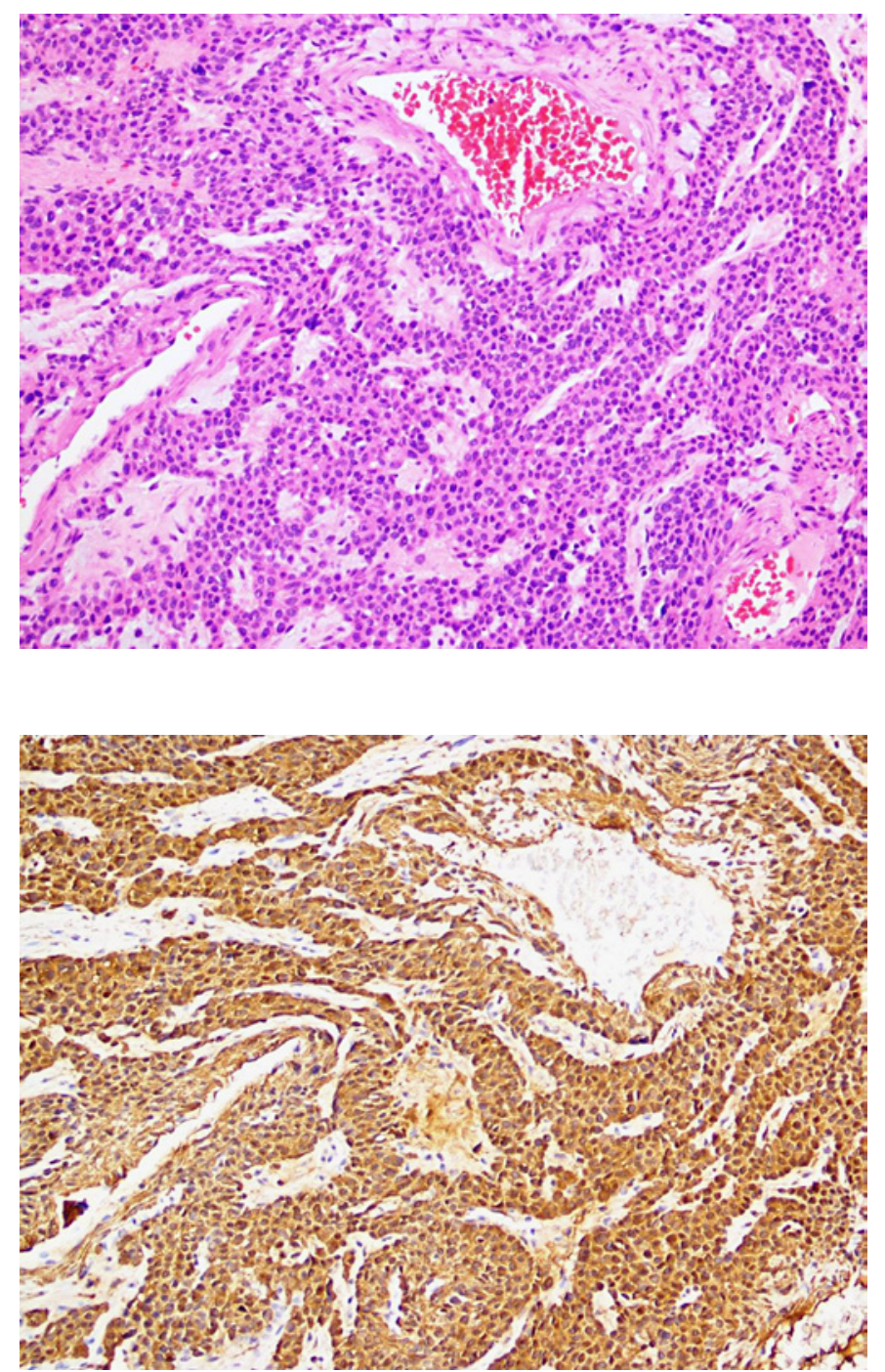

Although glomus tumors could be occurred anywhere, most common site of occurrence is known to in the digits, especially subungual area [2]. Glomus tumors have been thought to be found much in extradigital area. This thought might result in delayed- or misdiagnosis about extradigital glomus tumors. According to TK Schiefer et al. [6], extradigital glomus tumors were found approximately $61 \%$ of 137 cases at their institution during a 20 -yearperiod. Also, other study by Heys et al. [7] showed that $67 \%$ of 43 cases were extradigital tumors. Therefore, glomus tumors should be judged by not only location but also history, symptoms, and diagnostic images [6, 8].

Intradigital glomus tumor is common in female, while extradigital tumors are more common in men. Extradigital glomus tumors occur at a rate 4 times higher for men $[6,9]$. These tumors are mainly diagnosed between the fourth and seventh decades.

Glomus tumors present classical symptom triad of pain, pinpoint tenderness, and hypersensitivity to cold [10]. However, these typical symptoms are often invisible, making it difficult to diagnose extradigital glomus tumors. A glomus tumor must be considered in the differential diagnosis of any soft tissue mass such as a ganglion, neuroma, hemangioma, angioma, and so on. 
The most frequent site of extradigital glomus tumors is forearm, and there are some case reports about forearm glomus tumors. Chronic pain with tenderness around forearm glomus tumors $[11,12]$, asymptomatic glomus tumor [13], and skin color change around tumors [14, $15]$ were reported. These case reports show that extradigital glomus tumors are very difficult to diagnose because of various symptoms.

MRI has been shown to be the most sensitive modality, detecting $82-90 \%$ of glomus tumors in the hand [16]. The typical appearance on MRI is a well-margined mass of intermediate or low signal on T1-weighted images and high signal on T2-weighted images with diffuse enhancement. The specificity of MRI for detecting glomus tumors is $50 \%$, which is lower than high sensitivity [16].

A pathologic typical finding of glomus tumors is the regular cell spacing which is called "cookie-cutter appearance." It looks like the cells were created with a cookie cutter because the spacing between cells is equal and they all look very similar.

The treatment of glomus tumors is a complete surgical excision. If total extirpation is not done because of unclear operation field by hemorrhage, the recurrence rate of glomus tumors is high [11]. Therefore, usage of tourniquet to operate without bleeding results in reduced recurrence rates.

In this case, the patient was a 52-year-old female. The patient's gender was female though extradigital glomus tumor is developed in male dominantly. Of the triad of typical symptoms, only pain and pinpoint tenderness were shown except cold hypersensitivity. MRI result of the mass showed typical glomus tumor findings with enhancement pattern.

In conclusion, we presented an extradigital volar glomus tumor mimicking a painful ganglion. The diagnosis of extradigital glomus tumors is a challenge. Unusual location and nonspecific symptoms make the accurate diagnosis difficult. Hence, clinicians pay attention to history and diagnostic images besides symptoms.

\section{Statement of Ethics}

The patient provided written informed consent for the publication of clinical details and images.

\section{Conflict of Interest Statement}

The authors have no conflicts of interest to declare.

\section{Funding Sources}

The authors received no funding for this paper.

\section{Author Contributions}

D.G. Kim was involved in the surgery, data collection, manuscript preparation and its edition. S.R. Kang participated in the reviewing and interpretation. 


\section{Research}

\section{References}

1 Lee W, Kwon SB, Cho SH, Eo SR, Kwon C. Glomus tumor of the hand. Arch Plast Surg. 2015;42(3):295-301.

2 McDermott EM, Weiss AP. Glomus tumors. J Hand Surg Am. 2006 Oct;31(8):1397-400.

3 Carroll RE, Berman AT. Glomus tumors of the hand: review of the literature and report on twenty-eight cases. J Bone Joint Surg Am. 1972 Jun;54(4):691-703.

4 Wood W. On painful subcutaneous tubercle. Edinb Med Surg J. 1812 Jul 1;8(31):283-91.

5 Masson P. Le lomus neuromyoarteriel des regions tactiles et ses tumeurs. Lyon Chir. 1924;21:257-80.

6 Schiefer TK, Parker WL, Anakwenze OA, Amadio PC, Inwards CY, Spinner RJ. Extradigital glomus tumors: a 20-year experience. Mayo Clin Proc. 2006 Oct;81(10):1337-44.

7 Heys SD, Brittenden J, Atkinson P, Eremin O. Glomus tumour: an analysis of 43 patients and review of the literature. Br J Surg. 1992 Apr;79(4):345-7.

8 Panagiotopoulos E, Maraziotis T, Karageorgos A, Dimopoulos P, Koumoundourou D. A twenty-year delay in diagnosing a glomus knee tumor. Orthopedics. 2006 May;29(5):451-2.

9 Shugart RR, Soule EH, Johnson EW Jr. Glomus tumor. Surg Gynecol Obstet. 1963 Sep;117:334-40.

10 Van Geertruyden J, Lorea P, Goldschmidt D, de Fontaine S, Schuind F, Kinnen L, et al. Glomus tumours of the hand. A retrospective study of 51 cases. J Hand Surg Br. 1996 Apr;21(2):257-60.

11 Takei TR, Nalebuff EA. Extradigital glomus tumour. J Hand Surg Br. 1995 Jun;20(3):409-12.

12 Lee SK, Song DG, Choy WS. Intravascular glomus tumor of the forearm causing chronic pain and focal tenderness. Case Rep Orthop. 2014;2014:619490.

13 Lee YS, Lee YH. Glomus tumor in a extradigital lesion of forearm: a case report. Arch Hand Microsurg. 2015 12;20(4):176-9.

14 Nigam JS, Misra V, Singh A, Karuna V, Chauhan S. A glomus tumour arising from the flexor aspect of the forearm: a case report with review of the literature. J Clin Diagn Res. 2012 Nov;6(9):1559-61.

15 Schoenleber SJ, Rosenberg AE, Temple HT. Painful forearm mass in a 75-year-old man. Clin Orthop Relat Res. 2014 Feb;472(2):776-80.

16 Al-Qattan MM, Al-Namla A, Al-Thunayan A, Al-Subhi F, El-Shayeb AF. Magnetic resonance imaging in the diagnosis of glomus tumours of the hand. J Hand Surg Br. 2005 Oct;30(5):535-40. 